\title{
DIE NEDERDUITSE GEREFORMEERDE KERK, KERKORDE EN ONDERWYS
}

\section{Author:}

P J Strauss ${ }^{1}$

\section{Affiliation:}

${ }^{1}$ Ekklesiologie, Fakulteit: Teologie, Universiteit van die Vrystaat

\section{Correspondence to:}

P J Strauss

\section{Postal Address: \\ Interne Bussie 90 \\ Posbus 339 \\ Bloemfontein \\ 9300 \\ Email: \\ straussp@ufs.ac.za \\ Dates: \\ 31 Oct 2016}

How to cite this article: Strauss, P. J., 2016. "Die Nederduitse Gereformeerde kerk, kerkorde en onderwys". KOERS - Bulletin for Christian Scholarship, 81(2). Available at: http://dx.doi.org/10.19108/ koers.81.2.2256

\section{Copyright:}

(c) 2016. The Author(s).

Published under the Creative Commons Atribution License.

\section{The Dutch Reformed Church, church order and education.}

From the first church order of the General Synod of the Dutch Reformed Church in 1962, it has formulated stipulations for the church and education. In this regard the Dutch Reformed Church is unique among reformed churches. The wording of this article has changed over the years, but the main content has remained the same. The Dutch Reformed Church supports Christian education as a church, but also recognizes the competence of education authorities to finalise education standards and programmes. In 1962 the order of the Dutch Reformed Church on education also stated that the church would work on the Protestant character of the Afrikaner people. From 1990 onwards these words were omitted. The church nevertheless feels that education will allways be imbricated in a certain culture. In synodical resolutions in recent times the Dutch Reformed Church has recognized the calling of the South African state to subsidize all education enterprises that meet certain purely educational standards.

\section{Die Nederduitse Gereformeerde Kerk, kerkorde en onderwys}

Vanaf sy eerste kerkorde in 1962 koester die Algemene Sinode van die Nederduitse Gereformeerde Kerk die ideaal van nie-kerklike Christelike onderwys. Met sy kerkordelike bepalings oor die kerk en onderwys, is die Nederduitse Gereformeerde Kerk uniek onder gereformeerde kerke. Die bewoording van hierdie artikels het deur die jare verander, maar die hoofsaak het dieselfde gebly. Die Nederduitse Gereformeerde Kerk steun Christelike onderwys vanuit sy kerklike hoek, maar erken die interne bevoegdheid van onderwysinstellings om onderwysinhoude en standaarde te finaliseer. In 1962 het sy kerkorde bepaal dat die Nederduitse Gereformeerde Kerk hom beywer vir die Protestants-Christelike karakter van "ons volk", die Afrikanervolk. Die uitsondering van "ons volk" is sedert 1990 egter weggelaat ten gunste die erkenning van alle kulture in die onderwys. In sinodebesluite van die afgelope tyd ondersteun die Nederduitse Gereformeerde Kerk die standpunt dat die Suid-Afrikaanse staatsowerheid onderwys alle lewensbeskoulik gerigte instansies subsidieer. 


\section{INLEIDING}

Dat die kerk as kerk betrokke sal wees by die onderwys en opvoeding van sy dooplidmate (NGKO-VS 2013), spruit logieserwys uit die beloftes van die betrokke (verbonds-)ouers by die doop van hierdie kinders (Kleynhans 1988:200). Immers, die kerk wat amptelik die insiatief neem by die aflê van hierdie beloftes aanvaar daarmee amptelik ook toesig oor die nakoming van die beloftes.

Die beloftes beteken ondermeer dat die ouers hulle kinders sal opvoed - "onderrig en... laat onderrig" - in die "vrese" van die Here. Dat die ouers die kinders "van wie u vader en moeder (of voog) is" sal opvoed én laat opvoed om God in alles te gehoorsaam (NGK-Uitgewers 1986:61), 'n taak wat van hulle as ouers ook gehoorsaamheid vra. Ongehoorsaamheid wat kan lei tot tugwaardige sondes druis in teen die eise van die Here God se genadeverbond of die tien gebooie as sy lewensomvattende verbondswet (Deuteronomium 5 en 6). Hierdie ongehoorsaamheid lei onder sekere omstandighede tot die weerhouding van belydende lidmate van die gebruik van die doop en die nagmaal (NGKO 2013:17): 'n weerhouding van die sakramente of verbondstekens en -seëls as ' $n$ vorm van kerklike tug (Strauss 2010:98). Ongehoorsaamheid aan Gods verbondswet bring die geloofwaardigheid van die ouers in gedrang as hulle "voor God en sy gemeente" belowe om hulle gedoopte kind in hierdie gehoorsaamheid op te voed.

In gereformeerde kerke is daar ' $\mathrm{n}$ rangorde van dokumente wat as normatief beskou word.

Die eerste of hoogste norm of norma normans (norm van die norme) is die Bybel as die Woord van God. "Diep" hieronder as die tweede maar aan die Bybel gebonde en ondergeskikte norme, volg die belydenisskrifte van die kerk: die norma normata (Strauss 2010:81-83; Bavinck 1930:401). Derde in rangorde is die kerkorde wat ordelike kanale vir die heerskappy van die Woord en die belydenis van die kerk in die kerk moet voorsien - kanale wat slegs instrumente in diens van die heerskappy van die Bybel in die kerk moet wees en nie 'n doel op sigself is nie. Hierdie rangorde beteken dat die belydenisskrifte en die kerkorde ' $n$ groter meerderheid in kerkvergaderings vir hulle aanvaarding nodig het as ander "gewone" besluite. Vierde in rang lê die "gewone" besluite van kerkvergaderings (NGKO 2013:11,12, 24,25).

Teen hierdie agtergrond bevat ' $n$ goeie gereformeerde kerkorde bloot ordelike of praktiese kanale vir die regering van die Woord en die belydenis in die betrokke kerk, 'n orde met spaarsamige, kernagtige ordemaatreëls vir 'n Bybelsgehoorsame kerk (Strauss 2010:16), 'n orde wat Bybelse waarhede verwoord as ' $\mathrm{n}$ vertrekpunt, maar fokus op die kerklike praktyk. 'n Kerkorde wat die kerklike lewe of praktyk oorreglementeer of breedsprakerige bepalings vir die kerklike lewe maak, neig om die Woord te verduister en die kerk aan menslike reëls - in plaas van die Woord - te verkneg.

As ' $\mathrm{n}$ kerkorde dus bepalings vir die kerk oor nie-kerklike dagonderwys bevat, moet hierdie bepalings aan drie vereistes voldoen. In die eerste plek moet die bepalings die betrokkenheid van die kerk as kerk by die onderwys verwoord. In die tweede plek moet die bepalings praktiese kanale voorsien vir die kerk om as kerk Woordgetrou by die onderwys betrokke te wees. 'n Kerkorde moet wees wat die naam impliseer: 'n orde vir die Woordgetroue optrede van die kerk. In die derde plek moet hierdie betrokkenheid voldoen aan die tradisionele "kerklike sake op kerklike wyse" of, beter, "sake vanuit kerklike perspektief en op kerklike wyse" (Spoelstra 1989:177; Strauss 2010:57-62).

Die vraag is nou: voldoen die Kerkorde van die Nederduitse Gereformeerde Kerk (NGKO) in sy artikel oor "Kerk en onderwys" aan hierdie vereistes?

Die NGKO-2013 artikel 69 wat oor hierdie saak handel, bepaal:

69.1 Die Kerk beywer haar daarvoor dat die Woord van God en Protestants-Christelike norme en waardes rigtinggewend sal wees in onderwys- en opvoedkundige instellings en ook vir die kultuuridioom waarin die onderwys plaasvind.

69.2 Die kerk erken die interne bevoegdheid van onderwysinstellings om tipiese onderwysaangeleenthede (standaarde, leerinhoude, ensovoorts) te finaliseer.

69.3 Die kerk beywer haar vir Christelike opvoeding en onderwys vir haar kinders en jongmense. Hierdie onderwys moet verantwoorde standaarde en leerinhoude insluit.

Gevolglik ondersoek hierdie artikel, by wyse van onderbou, die volgende verbandhoudende vrae: wat is volgens die NGKO die aard van die betrokkenheid van die Nederduitse Gereformeerde Kerk (NGK) by die onderwys? Hoort hierdie aanduiding in 'n gereformeerde kerkorde? Watter gang of wysiginge het die artikel gevolg in die geskiedenis van die NGKO en waarom? Versterk die artikel die NGK se betrokkenheid by die onderwys?

Hoekom word dinge soos "kultuuridioom", "standaarde" en "leerinhoude" by die naam genoem? Laastens: bly NGKO artikel 69 by "sake vanuit kerklike perspektief...?" soos verwoord in artikel 21 (NGKO 2013:7)?

\section{DIE INHOUD EN BETEKENIS VAN NGKO ARTIKEL 69}

\subsection{Die konteks}

As ' $\mathrm{n}$ bepaling in 'n gereformeerde kerkorde' is NGKO 2013

$\overline{1}$ 'n Sleutelfiguur by die finalisering van die eerste NGKO in 1962, was dr JD Vorster, die eerste aktuarius van die eerste Algemene Sinode van die NGK én die voorsitter van die kommissie van aktuarii wat vir die opstel van NGKO 1962 verantwoordelik was. Vir hom was NGKO 1962 die "Dordtse Kerkorde(DKO) aangepas by die eise van die dag", Vorster 1960:13. By die opstel van NGKO het die destydse kommissie van aktuarii van die NGK die Kerkorde van die Gereformeerde Kerke in Nederland (GKNKO) as direkte voorbeeld gebruik. Hierdie Kerkorde wou ' $n$ eietydse weergawe van die DKO wees, Strauss 2010:7 en 8. Artikel 133 van die GKNKO het bepaal dat gemeentes moet toesien dat hulle kinders in Christelike skole onderwys ontvang. In ander skole moet die gemeentes van alle geleenthede gebruik maak om die "christelijke godsdienst" te onderrig (Nauta 1971:466). 
artikel 69 wat in NGKO 1962 artikel 67 en artikel 133 van die Kerkorde van die (nou) gewese Gereformeerde Kerke in Nederland sy voorlopers vind, uniek (NGKO 2013:20; NGKO 1964:15; vgl met bv Jansen 1952: Visser 1999; Engelhard \& Hofman 2001). Die feit dat die eerste NGKO, NGKO 1962, by die eerste Algemene Sinode van die NGK in $1962^{2}$ met ' $n$ bepaling oor die kerk en die onderwys wegspring, moet na alle waarskynlik egter òòk na die destydse omstandighede of Sitz im Leben van hierdie Kerkorde teruggevoer word. Daarom word teruggekom. Daarby het hierdie bepaling in die NGKO sedert 1962 min afgewyk van sy oorspronklike bedoeling, hoewel dit woordwysigings ondergaan het.

In die NGKO 1962 kom die bepaling oor die NGK en die onderwys onder die opskrif "Kerk en maatskappy" voor. Hierdie tema is self òò uniek in gereformeerde kerkordes. In latere NGKO's word "Kerk en Onderwys" 'n selfstandige tema (NGKO 1990:19).

In sy tipering van die destydse Suid-Afrikaanse samelewing gebruik die NGKO 1962 terme wat sy destydse konteks verraai. Die uitdrukkings "moderne gedifferensieerde samelewing", "selfstandigheid in eie bevoegdheid", "samelewingsverbande" en "gemeenskapstrukture" kom uit die twintigste-eeuse neoCalvinistiese Wysbegeerte en Wysgerige Sosiologie van HG Stoker (Potchefstroom - Wysbegeerte van die Skeppingsidee) en Herman Dooyeweerd (Amsterdam - Wysbegeerte van die Wetsidee) (vgl betoog in Strauss 1993:13). Vanuit hierdie beskouing maak die NGKO 1962 'n onderskeid tussen die kerk en die onderwys wat elkeen selfstandig op sy eie terrein binne die samehangende verskeidenheid van ' $n$ moderne gedifferensieerde samelewing funksioneer (die NGKO 1962 noem die kerk, staat, gesin, skool, verenigings en "partye" voorbeelde van samelewingskringe). Selfstandigheid binne 'n samehangende verskeidenheid beteken dat elkeen sy onvervreembare spesialisterrein het, maar ook raakvlakke waarin hulle mekaar vanuit ' $n$ eie fokus beïnvloed en ondersteun. Dit gaan hier om ' $\mathrm{n}$ neo-Calvinistiese lyn wat ook in ander dokumente van die NGK van dié tyd sigbaar is. "n Sprekende voorbeeld is die stuk "Ras, volk en nasie in die lig van die Skrif" van die Algemene Sinode van 1966 (NGK 1966:86; vgl. Strauss 1994:195-213). Hierdie dokument verteenwoordig die hoogbloei van steun in die NGK aan apartheid in die 1960's (De Gruchy 1979:70; Kinghorn 1986:129). Dit word ook gebruik in die soeke na ' $n$ beweerde aanknopingspunt in die denke van die bekende Nederlandse neo-Calvinis, Abraham Kuyper, vir die begronding van apartheid. Die NGKO 1962 kom tot stand in 'n tyd waarin die invloed van hierdie neo-Calvinisme op die NGK op die kruin van die golf is (Strauss 1994:203,206).

Die omstandighede van die NGKO 1962 verraai nie net die invloed van 'n Nederlandse neo-Calvinisme nie. Die blote feit dat die NGK hierin bepalings maak vir sy verhouding met sy onmiddellike samelewing verraai sy noue band met dié

2 Die sinodale verband van die NGK is in 1862 verbreek met die bekende Loedolffsaak in die Kaapse Hooggeregshof van daardie jaar. Dit het afgevaardigdes van gemeentes buite die Kaapkolonie sittingsreg op die Kaapse Sinode en daarmee sinodale eenheid met die gemeentes van hierdie Sinode ontsê. Hierdie eenheid is eers ' $n$ honderd jaar later, in 1962, herstel (vgl Van der Watt 1973:159). samelewing. Sy band met die destydse apartheidsregering of regerende Nasionale Party in Suid-Afrika kom byvoorbeeld tot uitdrukking in NGKO 1962 artikel 65. Te midde van die wêreldwye kritiek en druk op hierdie regering na die gebeure by Sharpeville in Maart 1960 en die protes en onrus uit die swart gemeenskap wat daarop gevolg het, verseker hierdie artikel die staat dat die NGK hom onderwerp aan die "gesag en wette van die staat" indien dit nie "met Gods Woord bots nie". Die "Kerk aanvaar met dankbaarheid (LW-PS) die beskerming deur die owerheid" en sy "vryheid van godsdiens in belydenis en byeenkoms, met dien verstande dat genoemde vryhede nie misbruik sal word om die fondamente van die staatsgesag te ondergrawe of om wanorde op publiekregtelike terrein te veroorsaak nie" (NGKO 1964:14).

Meer pastoraal-innig en kerklik-solidêr kan 'n kerkorde sy verhouding met sy staatsowerheid nouliks uitdruk. Ook dit is uniek aan die NGKO 1962!

Nog steeds vanuit hierdie noue band bepaal die NGKO naas die omskrewe betrokkenheid van die NGK by die onderwys, in artikel $67 \mathrm{~b}$ dat die NGK hom sal beywer om die "ProtestantsChristelike karakter van ons volk (LW-PS) te beskerm" en "uit te bou" (NGKO 1964:15). Gesien dat "ons volk" hier onder die tema "Kerk en maatskappy" voorkom, is dit nie denkbeeldig dat die begrippe volk en maatskappy as naby aan mekaar en selfs oorvleulend beskou word nie. Die "volkslewe" is destyds deur sommige as " $n$ sinoniem vir die samelewing waarin die NGK hom bevind, gebruik. Die NGK se betrokkendheid by die onderwys van "ons kinders" wat in dieselfde asem as "ons volk" gebruik word, is hieraan gekoppel. Die implikasie is dat die "volk" as een van die samelewingskringe "n omvattende samelewingsverband is wat bepalend op die ander kringe van die samelewing inwerk, ' $n$ denkpatroon wat die kerk in die versoeking lei om volksbelange bo Bybelse beginsels te stel (Strauss 1994:202,203; vgl. Kuyper 1870: 33).

Hierdie noue band is onteenseglik een van die redes waarom die NGKO 1962 bepalings bevat vir kerk, staat en maatskappy: vir kerk en onderwys. ' $n$ Voorloper van hierdie band kom in 1652 met Jan van Riebeeck na die Kaap wat die Nederlandsgereformeerde idee van die samelewing as ' $n$ eenheid waarin kerk, staat en volk verskillende kante van 'n teokratiese verbondsgemeenskap vorm, in Suider-Afrika oorplant (Pont 1988:36-53).

\subsection{Die bewoording en betekenis vanaf 1962}

Sekere bewoordings en grondoortuigings bly vanaf 1962 tot 2013 teenwoordig in die NGKO se bepalings oor die kerk en onderwys. Die formulering binne sy teksverband sowel as sy internkerklike NGK en Suid-Afrikaanse samelewingskonteks verander, maar die NGK se betrokkenheid by "die" onderwys vanuit ' $n$ Bybels-Christelike hoek, bly.

Die NGKO 1962 se "volkse" artikel 67.2 verdwyn na 1986 met die koms van die bekende dokumente "Kerk en samelewing 1986 en 1990" (NGKO 1990:19). Daarmee is "n lastige erfenis uit die 1960's verwyder. Immers, hoewel ' $\mathrm{n}$ volk as samelewingskring in sy kulturele gemeengoed Protestants-Christelik gerig moet wees én hoewel die kerk in sy profetiese roeping in die 
samelewing ook kultuurgroepe moet aanspreek, was hierdie koppeling met die Afrikanervolk vanweë die koppeling met apartheid omstrede. Hoekom die NGK as 'n kerk van Christus vir almal net op een volk konsentreer, was moeilik te verklaar.

Uitdrukkings soos die "Woord van God" op "n "ereplek" en "rigtinggewend", "Protestants-Christelike norme en waardes", die "selfstandigheid in eie bevoegdheid" of die "interne bevoegdheid" van onderwyinstellings, het gebly (NGKO 1964:15; NGKO 1990:19; NGKO 2013:20). Wysgerige terme soos moderne gedifferensieerde samelewing, verbande en gemeenskappe is vervang, maar dat die NGK Woordgebonde wil optree, ook in sy benadering van die onderwys in sy geheel, het gebly.

Die NGKO 1962 noem dit die roeping van die NGK om "toe te sien" dat die onderwys en opvoeding van die "jeug" deur erkende, selfstandige onderwysinstellings in ' $\mathrm{n}$ Christelike gees en rigting geskied. Hierdie roeping is ook die NGK se goddellike reg (NGKO 1964:15).

In hierdie stellings glinster daar iets van die onteenseglik invloedryke en sterk posisie van die NGK in die destydse SuidAfrika. Die NGK kan bepalend optree teenoor die onderwys deur "toe te sien". Hierdie formulering verraai "n kerklike vertroue of oortuiging dat sy woorde ernstig deur bepalende mense in die onderwys beskou word én moet word. Daarnaas baseer die NGKO 1962 hierdie kerklike roeping op 'n reg. 'n Reg wat nie betwis word nie en aan die NGK vaste grond vir sy optrede gee. Dat die NGK as 'n profetiese stem van God of vanuit 'n goddellike reg optree, gee aan hom gesag - binne en buite die vergadersale van die kerk - in Suid-Afrika.

Die volgende beduidende verandering aan hierdie formulering kom eers in die NGKO 1990 voor (NGKO 1990:19).

Op die skrapping van die "volkse" artikel is gewys.

Die "ereplek" vir die Woord van God in onderwys- en opvoedkundige inrigtings word gehandhaaf. 'n Saak wat op hierdie spesifieke tydstip bykom, is die nastreef van die "hoogste moontlike standaarde" deur opvoeders. Hierdie strewe word waarskynlik gebore teen die agtergrond van 'n veranderende Suid-Afrika waarin apartheid gegroet en 'n eenheidstaat met gelyke regte en geleenthede vir almal tegemoetgegaan word. 'n Eenheidstaat waarin onderwystelsels met 'n groot meerderheid uit die Derde Wêreld in Suid-Afrika gedeel word. 'n Integrasie wat vanselfsprekend die vraag na gemeenskaplike standaarde ook op die tafel plaas. Ook in die retoriek in die blanke politiek van daardie jare is die begrippe "beskaafde standaarde" of "standaarde" dikwels gehoor. Hiermee saam beywer die NGKO 1990 hom vir "behoorlik toegerusde leerkragte". Hierdie soort leerkragte is immers die noodsaaklike onderbou van die "hoogste moontlike standaarde".

In die aanloop tot 1990 weier die Algemene Sinode van 1986 om die woord "nasionaal" in die begrip "Christeliknasionale onderwys" vir opname in Kerk en samelewing 1986 te skrap. In sy kritiek teen apartheid wou die Sinode dus nie 'n positiewe Christelik-nasionaal ook kanselleer nie. Dieselfde Sinode verklaar dat die onderwys van alle bevolkingsgroepe gelykwaardig moet wees (NGK 1986:659). Gelyke standaarde én die volkseie staan, aldus die Sinode, nie teenoor mekaar nie.

In 1990 beskou die NGK dit steeds as sy roeping om "toe te sien" - terwyl hy die "soewereiniteit in eie kring" van "alle" onderwysinrigtings (primêr, sekondêr en tersiêr) erken - dat sy jeug Christelike opvoeding en onderwys ontvang. Die spook van marginalisering in die "nuwe" Suid-Afrika loop nog nie by hom nie. Die verwysing na Afrikanervolk in die artikel word geskrap en vervang met die meer algemene behoefte van die NGK vir die "Protestants-Christelike karakter van kultuur-georiënteerde onderwys". Een volk of "ons volk" word nie meer uitgesonder nie maar tog word die opvoeding van "jong Afrikanertjies" aan die hand van Protestants-Christelike waardes ook hierin vervat.

Naas die wysiging van die NGKO oor die kerk en die onderwys, besluit die Algemene Sinode van 1990 ook op 'n aantal breër uitgewerkte standpunte oor die NGK en "opvoeding en onderwys" (NGK 1990:612-613) - besluite wat nie in die Kerkorde opgeneem word nie, maar tog fyner nuanses van die houding van die NGK op daardie stadium weergee (nuanses wat uit ' $\mathrm{n}$ prosedureoogpunt in die verlengde van die NGKO moet lê).

Volgens die Sinode word Christelike opvoeding en onderwys gebaseer op die onfeilbare Woord van God. Dit gaan oor opvoeding en onderwys aan syverbondskinders: in die huisgesin en daarbuite. Die boodskap van die Woord word verstaan en vertolk deur die "gereformeerde belydenisskrifte". Elke kind moet aan die hand van die Woord begelei word om tot eer van God sy/ haar volle potensiaal te bereik. Die kerk, die staat en die ouers is in ' $\mathrm{n}$ vennootskap wat hulle verantwoordelikheid vir die onderwys betref. Die kerk moet die opvoeding en onderwys van sy verbondskinders op formele en nie-formele vlakke "aanvul en versterk". Hierdie opdrag impliseer ook " $\mathrm{n}$ "deurlopende pastorale begeleiding en ondersteuning" van leerlinge en ouers wanneer hulle in die nuwe omstandighede waarby hulle hulle moet aanpas, kom. Hierdie omstandighede is die verwagte "minder beskermde onderwysmilieu" - vir Christelik-nasionale onderwys. Vier jaar voor 1994 het die Algemene Sinode van 1990 dus reeds ' $n$ vae aanvoeling van die nuwe situasie waarin die politieke oorgang van 1994 die onderwys in Suid-Afrika sou kon plaas. In dié proses huiwer daar 'n onsekerheid en vrese vir die onbekende.

Die Algemene Sinode van 1990 noem moedertaalonderwys ' $\mathrm{n}$ besondere kommunikasiemiddel van wesenlike belang vir opvoeding en onderwys. Daarby moet gelyke onderwysstandaarde vir elke inwoner van Suid-Afrika ongeag ras, kleur, geloof of geslag nagestreef word. Die finansiële steun van die staat moet ook gegee word aan mense wat ' $n$ "besondere religieus-lewensbeskoulike beklemtoning in die onderwys verlang."

Die Algemene Sinode van 1998 sorg vir die huidige bewoording vervat in die NGKO 2013.

\subsection{Die huidige bewoording en betekenis}

In 1998 ondergaan die NGKO ' $\mathrm{n}$ hersiening wat die nuwe tyd in Suider-Afrika na die oorgang in Suid-Afrika in 1994 probeer verreken. Die NGKO wil immers 'n orde vir die NGK 
in sy nuwe omstandighede bly. Die bewoording van, op daardie stadium, artikel 67, bevat dieselfde kernsake as vroeër, maar in ' $n$ nuwe baadjie. Hierdie artikel 67 bly sedertdien inhoudelik onveranderd, maar teen 2013 word dit artikel 69 (NGKO 2013:20). Die enkele verandering wat aangebring is, is bloot redaksioneel.

HIervolgens is die NGK nie meer "n "hom" nie, maar " $\mathrm{n}$ "haar" 'n wysiging wat nou in artikel 69.1 en 69.3 voorkom. Die rede hiervoor is waarskynlik niks meer as die ou vraag nie: praat jy van die kerk as manlik of vroulik? Met die inbring van die NGK as vroulik gee die NGKO egter gestalte aan die Bybelse beeld van die kerk as die bruid van Christus én ' $n$ meer vrouvriendelike benadering wat na die formele aanvaarding van 'n akte van menseregte in 1996 (Constitutional Assembly 1997), goed kan oorkom.

Soos in 1990 word sekere sleutelterme behou.

Die groot saak is steeds dat die NGK hom daarvoor beywer dat die Bybel en Protestants-Christelike norme en waardes rigtinggewend sal wees in alle soorte onderwys: ook vir die kultuuridioom waarin hierdie onderwys plaasvind. Die NGKO praat nou van die "interne bevoegdheid" van onderwysinstellings om tipiese onderwysaangeleenthede soos standaarde en leerinhoude te finaliseer. Behalwe dat die NGK hierdie soort onderwys in die algemeen bepleit, beywer hy hom ook vir "Christelike opvoeding en onderwys" vir sy eie kinders en jongmense as verbondskinders.

Oor kerk en onderwys loop die NGKO 1998 en 2013 dus steeds op die spoor van NGKO 1962 (NGKO 1998: 26; NGKO 2013:20; NGKO 1964:15). Sleutelterme is die behoefte aan Christelike onderwys en opvoeding aan verbondskinders deur onderwysinstellings waarvan die eie interne bevoegdheid om die inhoud van die onderwys te finaliseer, deur die NGK erken word.

Aan die begin van die nuwe bedeling in Suid-Afrika waarvan die inhoud nog nie ten volle duidelik is nie, kom die Algemene Sinode van 11-20 Oktober 1994, 'n paar maande na die oorgang op 27 April, met ' $\mathrm{n}$ aantal aanvullende besluite oor kerk en onderwys.

Die Sinode "herbevestig die noodsaak van Bybelonderrig as onderbou van " $n$ opvoedingsprogram aan sy verbondskinders". Alle skoolleerlinge behoort egter toegang te hê tot ' $n$ nieakademiese religieuse vak waarin hulle in hulle eie geloof onderrig word. NGK-lidmate moet "toesien" dat hulle skoolkinders Bybelonderrig ontvang. Indien die vak nie aangebied word nie, kan ouers met gewetensbesware hulle kinders aan ander religieuse "studies" onttrek (NGK 1994:450). Die Sinode bly dus by die waarde van Bybelonderrig op skool, maar het ook ' $\mathrm{n}$ oog vir die nuwe multireligieuse bedeling, ' $\mathrm{n}$ bedeling waarin die vryheid van godsdiens erken word en staatsdwang ten gunste van die Christelike geloof soos onder Gratianus en Theodosius in $380 \mathrm{nC}$ in die Romeinse Ryk (De Jong 1987:56) - nie aanvaarbaar is nie. Die Sinode voorsien dus die moontlikheid van ' $n$ multireligieuse benadering in staatskole in die nuwe bedeling. Die NGK wil onderwys vanuit ' $\mathrm{n}$ Christelike hoek benader, maar die ou bedeling van ' $n$ Teokratiese eenheidsgemeenskap skyn verby te wees. In die plek daarvan is daar skynbaar - dit is die waarneming - 'n godsdiensneutrale, maar nie antigodsdienstige nie, staat (NGK 1994:148).

Daarom versoek die Algemene Sinode van 1994 die nuwe Suid-Afrikaanse "staat" om "ruimte te skep vir die skole met ' $n$ Christelike grondslag waarin die Woord van God steeds 'n sentrale plek" inneem. Die Sinode bepleit dieselfde ruimte ook vir skole met "n "kultuurgerigte grondslag" (NGK 1994:451). Die besef dat dieselfde voorregte én regte alle burgers van Suid-Afrika toekom, dat die gelykheid van alle mense in die nuwe denk- en politieke era ' $n$ maatstaf vir geregtigheid is, is nou deel van die denkgoed van die Algemene Sinode.

Met sy kultuurgerigte grondslag bedoel die vergadering waarskynlik skole gerig op 'n bepaalde kultuur omdat kultuur in elke geval die kleed is waarin onderwys en opvoeding plaasvind. 'n Skool sou onder hierdie formulering kon kies om ' $\mathrm{n}$ bepaalde taal en kultuur in sy doen en late te bedryf én te koester. Weer eens het die Sinode die kinders van sy eie kultuurgemeenskap òòk in die oog.

Dieselfde Sinode moedig kerkrade, ringe en sinodes aan om lidmate in "die plaaslike gemeenskap" toe te rus om vir "die Christelike godsdiens" in skole te beding. Die staat moet "private kerkskole" ook subsidieer om ouers wat dit verkies, in staat te stel om "Christelike onderwys" vir hulle kinders te verseker. Terselfdertyd het die Sinode "hoë waardering" vir onderwysers, dosente en onderwysleiers wat die onderwys onbaatsugtig dien en hulle Christenskap daarin uitleef. Die NGK moet voortgaan met die werwing en steun van Christenonderwysers en 'n Christelike vakonderrig (NGK 1994:451)'.

Teen die agtergrond van hierdie besluite handhaaf die NGKO 1998 vier jaar later ' $n$ voorkeur vir Christelike opvoeding en onderwys - onderwys en opvoeding in staats- én nie-staatskole. Hiermee handhaaf die Algemene Sinode van die NGK van 1998 dus die tradisionele uitgangspunte van die NGK ten opsigte van die onderwys (Strauss 2013:32).

Terselfdertyd gee hy ' $\mathrm{n}$ nuwe, moderne formulering van die quia- of omdat-dit-met-die-Skrif-ooreenkom-standpunt in sy aanvaarding van die Drie Formuliere van Eenheid as gereformeerde belydenisskrifte. Hy herstel ook sy bevriesde lidmaatskap van die Wêreldbond van Gereformeerde Kerke. 'n Bond waaruit hy in 1982 omrede sy teologiese en morele steun aan ' $n$ rasgeorienteerde en onderdrukkende apartheid, geskors is. 'n Steun wat hy nou - op versoek van die Wereldbond uitdruklik afwys. Hierdie Algemene Sinode word later beskryf as ' $\mathrm{n}$ bestendiger van gereformeerde standpunte in ' $\mathrm{n}$ nuwe bedeling (Strauss 2013:32).

\footnotetext{
$3 \quad$ Hiermee kies die Algemene Sinode van 1998 uitdruklik vir 'n Christelike wetenskap ( $v g \mathrm{l}$ die eertydse PU vir $\mathrm{CHO}$ ) en nie maar net die Christen in die wetenskap nie (vgl Potgieter 2008:170-171).
} 


\section{DIE NGKO 2013 ARTIKEL 69 GEWEEG}

Uit hierdie weergawe van die verloop van die bepalings oor "Kerk en onderwys" in die NGKO sedert 1962 spruit daar relevante vrae uit die doel van hierdie artikel: het die NGKO die ideaal van die NGK oor sy betrokkenheid as kerk by "die" onderwys reg verwoord? Was die NGKO hiermee tipies kerkordelik? Het die NGKO hierdie bepalings as blote kanale vir kerklike optrede geformuleer? Het die NGKO hom in dié proses gehou by sake vanuit ' $n$ kerklike perspektief en op ' $n$ kerklike wyse?

Die NGK se standpunt oor die kerk en onderwys vloei uit ' $n$ grondhouding wat reeds in die Nederlandse era of in die tyd van die Verenigde Oos-Indiese Kompanjie (1652-1806) aan die Kaap voorgekom het. In sy verduideliking van Christelik-nasionale onderwys wys Kapp daarop dat hierdie onderwys "ten nouste" aan die Nederlandse Gereformeerde Kerk (aan die Kaap later die NGK genoem, Strauss 2015:16) "verbonde was". Die Christelike of gereformeerde leer en beskouing ${ }^{4}$ moes die grondslag vorm van die nasionale of "vaderlandsgerigte" karakter van die onderwys. Kapp noem drie "bene" vir Christelik-nasionale onderwys: die Christelike godsdiens, die reg op onderwys in die eie taal, sedes, kultuur en geskiedenis en die huisgesin as die primêre opvoeder (Kapp 2008:171). Die betrokkenheid van die huisgesin, kerk en staat by hierdie onderwys was ook 'n konsekwensie van die verstaan van die gemeenskap as ' $\mathrm{n}$ Teokratiese eenheidsof verbondsgemeenskap soos uit Nederland ingevoer, ' $\mathrm{n}$ eenheidsgemeenskap wat samewerking tussen kerk en staat as twee kante van dieselfde munt of twee kante van die bevolking impliseer. Dieselfde opvatting het later meegebring dat die Wenkommando as 'n militêre eenheid die Gelofte van 1838 voor die Slag van Bloedrivier kon aflê (Pont 1988:36-53; Strauss 2001:817-818), 'n Gelofte waarin die kommando as "n militêre instelling die "Heilige God van Hemel en aarde" direk in 'n gebed aanspreek (Strauss 2001:821-824) .

Hoewel in ander tye met ' $n$ ander konteks en anders verwoord, bly die NGKO by sy ideaal van Christelike onderwys - Christelike onderwys in ' $n$ kultuuridioom wat deur die betrokke onderwysinstellings self gekies word, dus onderwysinstellings wat oor 'n erkende interne bevoegdheid beskik om vakinhoude en -standaarde te bepaal, maar wat die Christelike begronding en rigting daarvan - indien die betrokke instelling kies vir 'n Christelike inslag - met die kerk deel. Onderwysinstellings in ' $n$ multigodsdienstige en lewensbeskoulik-gedifferensieerde samelewing wat deur die NGK erken en gerespekteer word: ook ten opsigte van nie-Christelik georiënteerde onderwys. Die NGK beskou dit so dat die subsidie van die staat aan alle onderwysinstellings moet gaan wat aan sekere standaarde voldoen en dat die staat nie vir ' $\mathrm{n}$ bepaalde godsdienstige en lewensbeskoulike rigting in die onderwys moet kies nie. Soos ten

$4 \quad$ In sy formuliergebed by die aanwalgaan aan die Kaap van sy Nederlanders in April 1652 bid Jan van Riebeeck dat hulle die "ware Gereformeerde Christelijke leer" onder die "wilde en astrante" mense van Suider-Afrika sal verbrei (Hofmeyr et al. 1991:6,7).

' $n$ Gelofte is immers ' $n$ belofte aan die Here... Dit word direk met die Here God opgeneem (Cilliers 1876:125). opsigte van kerk en godsdiens moet die staat lewensbeskoulik neutraal optree teenoor alle onderwysinstellings.

In hierdie verband het die NGKO deur die jare vanaf 1962 tot 2013 die NGK se kerklike belang en betrokkendheid die onderwys reg verwoord. Hoewel die Algemene Sinode homself nie daaroor uitspreek nie en slegs ' $n$ algemene goedkeuring van die staat soek vir, indien verlang, "kerkskole", impliseer sy klem op behoorlike standaarde dat hierdie skole òòk gemeet moet word aan behoorlike skoolstandaarde. Kerkskole kan nie aanvaar word bloot omdat die betrokke kerk aanvaarbaar is of omdat die skool in 'n kerklike opsig diens lewer nie. Kerkskole moet aan behoorlike onderwysstandaarde voldoen omdat hierdie skool òò op die onderwys fokus en geen kerk is nie. Soos enige skool sy leerders in hulle algemene mensontwikkeling stimuleer, moet kerkskole én Christelike publieke en privaatskole van sy leerders beter burgers van die staat en goeie lede van die samelewing maak. Hoewel nêrens in detail uitgewerk nie, is hierdie gevolgtrekkings moontlik binne NGKO.

In die NGK se hantering van die onderwys sedert 2000 was daar geen behoefte om die NGKO te wysig nie.

Bevat die NGKO artikel 69 as kerkorde egter die nodige instrumente om uitvoering te gee aan die tipies kerklike standpunte van die NGK oor die onderwys? Op die keper beskou is hierdie artikel binne die algemene klimaat van die NGK oor die onderwys niks meer as ' $\mathrm{n}$ algemene standpuntstelling of vertrekpunt wat niemand in hierdie kringe sigbaar aanspreek of verontrus nie. Dit is asof die NGKO volstaan met sy houding sonder om - in 1962 én 2013 -die NGK te rig in een of ander breë kerklike rigting van praktiese optrede in Suider-Afrika. Die NGKO is vir baie jare boonop die kerkorde van die NGK in Namibië en Zimbabwe. Tog is die NGKO en besluite van die Algemene Sinode op die situasie in Suid-Afrika alleen gerig. Kan ' $\mathrm{n}$ kerkorde nie meer verantwoordelikheid aan gemeentes opdra ten opsigte van Christelike onderwys in hulle omgewing of gesamentlik nie? As kerkregering vanuit 'n Christelike vertrekpunt die regering van die Woord van God is, spoor die Woord die NGK nie hier aan tot praktiese dade nie? Is die NGK tevrede met wat in Suider-Afrika aan Christelike onderwys in staats- en privaatskole gedoen word? Of versoen hy hom met - 'n deeglike wetenskaplike ontleding ontbreek nog hier - die gebrekkige status quo? Waarom bly daar 'n behoefte aan geloofwaardige Christelike privaatskole? Waar is ' $n$ prikkelende, motiverende kerklike debat?

Watter konkrete hulpdiens lewer die NGK aan sy verbondsouers om hulle doopbelofte na te kom? Sou 'n NGKO nie hierin 'n rol kon speel nie?

Dat Christelike onderwys op sigself beskou ' $n$ saak is wat vanuit 'n kerklike perspektief en op 'n kerklike wyse ywerig aangepak kan word, is nie in die geskiedenis van gereformeerde kerke ontken nie (Jansen 1952:143; Spoelstra 1989:181-182). In sy algemene trant of benadering hou die NGKO ook nie vir die NGK ' $\mathrm{n}$ bedreiging ten opsigte van sy eie artikel 21 in nie: "Sake vanuit "n kerklike perspektief..." (NGKO 2013:7). Die naaste wat die NGKO aan die terrein van die skool kom, is sy onderstreping van die "hoogste moontlike standaarde" (NGKO 1990:19) en "verantwoorde 
standaarde en leerinhoude" (NGKO 2013:20). Die implikasie van hierdie formulering is egter dat Christelike onderwys nie minderwaardig hoef te wees nie, maar ook aan die hoogste standaarde kan of moet beantwoord. "Op standaardwees" is " $n$ breë beginsel waarin die betrokke standaard nog nie vasgestel is nie. Onderwyskundiges moet hierdie standaarde self vasstel.

'n Woordgetroue kerkorde bestaan uit funksionerende instrumente vir kerklike optrede omdat hierdie instrumente Bybelsrelevant is en die Skrif in die betrokke kerk lewe.

\section{SLOT}

Die wenslikheid van NGKO 2013 artikel 69 se tema "die kerk en onderwys" is Bybels-gereformeerd en kerkordelik verantwoord. Dit dra 'n ideaal wat met die NGK in 1652 na die Kaap gekom het (Strauss 2015:5). Veranderinge aan die bewoording van die NGKO 1962 sedert 1962, het niks aan hierdie ideaal verander nie. Die ideaal is kerklik aanvaar en ingeburger.

Tog ontbreek dit hierdie bepalings aan 'n tipies kerkordelike impak.

Die vraag is ook of die onderwysbetrokkenheid van die NGK as kerk armer sal wees sonder die NGKO 2013 artikel 69? Wat maak hierdie kerklike standpunte nodig in 'n kerkorde? Moet ' $\mathrm{n}$ nuwe kerkordelike formulering nie die huidige situasie in Suider-Afrika onder die loep neem en maatreëls verwoord wat dit kan beïnvloed en verander nie? Watter praktiese rol kan die NGK nou speel om Christelike onderwys in die algemeen in Suider-Afrika te bevorder? 'n Kerkorde is immers ingestel en op kerklike optrede en nie soseer 'n uitdrukking van kerklike houdings of ' $n$ kerklik-etiese dokument nie! Hierdie houdings dien eerder as die agtergrond van kerkordelike reëlings.

Intussen handhaaf die NGK sy onafhanklike kerklike houding in Suider-Afrika òòk met die NGKO 2013 artikel 69. 'n Relevante kerkorde gee egter rigting aan die uitlewing van hierdie houding.

\section{BIBLIOGRAFIE}

Bavinck, H. 1930. Gereformeerde Dogmatiek IV. Kampen: Kok.

Cilliers, S.A. 1876. Journaal. In: Gerdener, GBA 1919. Sarel Cilliers, die vader van Dingaansdag. Kaapstad: Samuel Griffiths, 112-132.

Constitutional Assembly 1997. The constitution of the Republic of South Africa. Wynberg: Constitutional Assembly.

De Gruchy, J. 1979. The church struggle in South Africa. Cape Town: David Philip.

Engelhard, D.H. \& Hofman, L.J. 2001. Manual of Christian Reformed Church Government. Grand Rapids: CRC.

Hofmeyr, J.W., Millard, J.A. \& Froneman, C.J.J. 1991. History of the church in South Africa. Pretoria: Unisa.

Jansen, J. 1952. Korte verklaring van de Kerkorde der Gereformeerde Kerken. Kampen: Kok (3e druk).

Kapp, P.H. 2008. Christelik-nasionale onderwys. In: Gaum F (hoofred). Christelike Kernensiklopedie. Wellington: Lux Verbi, 171.

Kinghorn, J. (red.) 1986. Die NG Kerk en apartheid. Johannesburg: Macmillan.

Kleynhans, E.P.J. 1988. Gereformeerde Kerkreg IV. Pretoria: NG Kerkboekhandel.

Kuyper, A. 1870. Eenvormigheid, de vloek van het moderne leven. Amsterdam: sn (2e druk).

Nauta, D. 1971. Verklaring van de Kerkorde van de Gereformeerde Kerken in Nederland. Kampen: Kok.

Nederduitse Gereformeerde Kerk (NGK) 1966, 1986, 1990. Handelinge van die Algemene Sinode. Sl:sn.

Nederduitse Gereformeerde Kerk (NGKO) 1964. Kerkorde. Kaapstad: NG Kerk-Uitgewers.

Nederduitse Gereformeerde Kerk (NGKO) 1990. Die Kerkorde. Doornfontein: Perskor.

Nederduitse Gereformeerde Kerk (NGKO) 1994. Die Kerkorde. Wellington: Hugenote.

Nederduitse Gereformeerde Kerk (NGKO) 1998. Die Kerkorde. Wellington: Hugenote.

Nederduitse Gereformeerde Kerk (NGKO) 2013. Die Kerkorde. Sl:sn.

Nederduitse Gereformeerde Kerk Vrystaat (NGKO-VS) 2013. Kerkorde. Sl:sn. 
NG Kerk-Uitgewers 1986. Handboek. Pretoria: NG Kerkboekhandel.

Pont, A.D. 1988. Die Gelofte van 1838 - 'n poging om die teologiese agtergrond daarvan te peil. In: Pont, A.D. (red.). Die Gelofte van 1838, 38-53. Pretoria: HAUM.

Spoelstra, B. 1989. Gereformeerde Kerkreg en Kerkregering. Hammanskraal: Teologiese Skool.

Strauss, P.J. 1993. Op die tweesprong? Bloemfontein: UV.

Strauss, P.J. 1994. Die Algemene Sinode van 1966 van die Nederduitse Gereformeerde Kerk en apartheid. Studia Historiae Ecclesiasticae XX/2, 195-214.

Strauss, P.J. 2001. Nogeens: die agtergrond, inhoud en implikasies van die Gelofte van 1838. HTS 57/3 en 4, 814-834.

Strauss, P.J. 2010. Kerk en orde vandag. Bloemfontein: Sunmedia.

Strauss, P.J. 2013. Kerkwees in die branding. Die NGK in algemene sinodale verband 1994-2011. Bloemfontein: Sunmedia.

Strauss, P.J. 2015. Gereformeerdes onder die Suiderkruis 1652-1911. Bloemfontein: Sunmedia.

Van der Watt, P.B. 1973. Die Loedolffsaak en die Nederduitse Gereformeerde Kerk 1862-1962. Kaapstad: Tafelberg.

Visser, J. 1999. Die Kerkorde in praktyk. Orkney: EFJS.

Vorster, J.D. 1960. Die kerkorde vir die NG Kerke. NGTT, Sept 1960, 12-18. 